\title{
INFLUENCE OF COMPENSATION OF SELENIUM DEFICIENCY ON IMMUNOLOGICAL PARAMETERS OF PATIENTS WITH MULTIDRUG-RESISTANT TUBERCULOSIS AT THE BACKGROUND OF SUBCLINICAL HYPOTHYROIDISM
}

\author{
Svitlana MATVYEYEVA, PhD., associate professor \\ Kharkov national medical university
}

\section{Summary.}

In 60 patients with multidrug-resistant tuberculosis at the background of subclinical hypothyroidism serum level of selenium, thyroid state and immunological parameters were studied in dynamic of the intensive phase of chemotherapy. Initially low level of selenium, subclinical hypothyroidism and weaken immunological response toward tuberculosis were diagnosed. Prescribing of selenite sodium with $200 \mu$ daily during 60 daily doses normalized serum level of selenium, restored thyroid function and improved immunological response. Using of selenite sodium like an accompanying medicine during chemotherapy of multidrug tuberculosis at the background of subclinical hypothyroidism after estimation of serum level of selenium is recommended.

Keywords: multidrug-resistant tuberculosis, thyroid gland, sodium selenite, chemotherapy.

Резюме. Влияние компенсации селенодефицита на показатели иммунитета у больных мультирезистентным туберкулезом на фоне субклинического гипотиреоза.

У 60 больных мультирезистентным туберкулезом на фоне субклинического гипотиреоза изучались уровень селена в сыворотке крови, тиреоидный статус и показатели иммунитета в динамике интенсивной фазы химиотерапии. Диагностирован начальный низкий уровень селена, субклинический гипотиреоз и снижение иммунного ответа на туберкулезную инфекцию. Назначение 60 суточных доз селенита натрия по 200 мг нормализовало уровень селена в сыворотке крови, восстановило функцию щитовидной железы и улучшило иммунологический ответ. Рекомендуется назначение селенита натрия как препарата сопровождения при проведении химиотерапии пациентам с мультирезистентным туберкулезом на фоне субклинического гипотиреоза после оценки уровня селена в сыворотке крови.

Ключевые слова: мультирезистентный туберкулез, щитовидная железа, селенит натрия, химиотерапия.

The currency of the problem of treatment of multidrug-resistant tuberculosis is determined by the increase in the last 10-20 years in the frequency of drug resistance of Mycobacterium tuberculosis to isoniazid and rifampicin, as well as to other, often many anti-tuberculosis drugs. Cure of such patients is possible in $50-60 \%$ of cases, and patients with extended drug resistance - only in $29-30 \%$. In this situation, the ability of the body to form an adequate immune response to tuberculosis infection is especially important. It is known that the thyroid gland by direct and indirect pathways (possibly through protein kinase-C) activates cells of the monocytic-macrophage system, contributing to the elimination of the tuberculosis pathogen from the body [8]. The form of a specific immune response is controlled by cytokines, which are formed during the body's inflammatory response to tuberculosis infection. By modulating key defense reactions, cytokines regulate the interaction between the immune and endocrine systems at the systemic level [12]. Hypothyroidism worsens the results of anti-tuberculosis chemotherapy due to the ad- verse effect of thyroid hormone deficiency on T-cell immunity. Thyroid hormone metabolism depends on the combined action of selenoproteins known as iodothyronine deiodinases $[5,14]$. Selenium deficiency affects the function of the thyroid gland, as proven by numerous studies [6]. Thus, the study of the parameters of immunity in patients with chemoresistant tuberculosis against the background of hypothyroidism in conditions of selenium deficiency and its compensation is current.

The object of the study to detail the compensation of the selenium-deficiency of on immunological indexes in patients with multi-drug resistant tuberculosis (MDR TB) and concomitant subclinical hypothyroidism (SH).

Materials and methods: The study included 60 patients with multidrug-resistant pulmonary tuberculosis (MDR TB) with concomitant subclinical hypothyroidism. The patients were divided in 2 groups: 30 patients in observation group (MDR $\mathrm{TB}+\mathrm{SH}+\mathrm{Se}$ ) received 60 daily doses of $200 \mu \mathrm{g}$ of selenite sodium during intensive phase of individual antituberculosis 
chemotherapy based on the ground of drug-resistant test results and other 30 patients of control group $(\mathrm{MDR} \mathrm{TB}+\mathrm{SH})$ received individual antituberculosis chemotherapy only. Before starting treatment and at the end of intensive phase, serum levels of selenium in the laboratory "Synevo" (Germany) on the analyzer "Perkin Elmer Zeeman 4110", free thyroxine $\left(\mathrm{T}_{\text {free }}\right)$, thyroid-stimulating hormone of the pituitary gland (TSH) were determined by the immunoenzymatic method. At the same time, the state of T- and B-systems of immunity, natural killers were assessed. Phenotyping of lymphocytes was carried out and the relative content of $\mathrm{T}$ cells was determined: $\mathrm{CD} 3+$, T-helpers $\left(\mathrm{CD}^{+}\right)$, cytotoxic T-cells $(\mathrm{CD} 4+)$, B-lymphocytes $\left(\mathrm{CD} 19^{+}\right)$and natural killer cells $\left(\mathrm{CD} 16^{+}\right)$. Using Vector Best reagents, the cytokine profile was determined: the levels of tumor necrosis factor- $\alpha$ (TNF- $\alpha$ ), interferon- $\gamma$ (INT- $\gamma$ ), interleukin-2 (Il-2), -6 (Il-6) and -4 (Il-4) before starting treatment and at the end of intensive phase. Statistical processing of the obtained data was carried out by the method of variation statistics using a standardized package of calculations Microsoft Excel XP. The probability of discrepancy between the mean values was determined by the Student's t test. The critical level of significance $(\mathrm{P})$ when testing statistical hypotheses was taken equal to 0.05 .

\section{Results.}

The results of the study of the serum level of selenium and the hormonal profile of both groups are presented in Table 1.
As a result of the study, in both groups of patients with multi-drug resistant tuberculosis with subclinical hypothyroidism, low-normal levels of free thyroxine and increased levels of thyroid-stimulating hormone of the pituitary gland were established. The data obtained indicate a tendency towards a decrease in thyroid function in patients with chemoresistant tuberculosis. The weakening of the functional activity of the thyroid gland is confirmed not only by a decrease in the level of free thyroxine, but also by an increase in the secretion of thyroid-stimulating hormone of the pituitary gland due to negative feedback in the system of the thyroid gland - thyroid-stimulating hormone of the pituitary gland.

The study also found that the average value of the level of selenium in the free blood flow in patients with chemo-resistant tuberculosis is reduced: both in the observation group $(56.66 \pm 6.85) \mu \mathrm{g} / \mathrm{L}$ and in the comparison group $(57.04 \pm 7.16) \mu \mathrm{g} / \mathrm{L}$ compared to the norm $(74.0-139.0) \mu \mathrm{g} / \mathrm{L}$.

During chemotherapy, as the intoxication disappeared and metabolic processes were restored, the level of selenium in the free blood flow increased. A more significant increase in the level of selenium was observed in the observation group when compared with the control $(107.02 \pm 8.54$ and $60.53 \pm 8.45 \mu \mathrm{g} /$ 1 , respectively). In patients who received selenium sodium, an increase in the function of the thyroid gland was noted, as can be judged by an increase in the level of free thyroxine. At the same time, in the comparison group, the average level of free thyroxine significantly

Table 1

Serum levels of free thyroxine, thyroid stimulating hormone, selenium and indexes in patients with MDR TB with subclinical hypothyroidism

\begin{tabular}{|c|c|c|c|c|}
\hline \multirow[b]{2}{*}{ Parameters } & \multicolumn{2}{|c|}{ MDR TB+SH+Se $(n=30)$} & \multicolumn{2}{|c|}{ MDR TB+SH $(n=30)$} \\
\hline & Before treatment & $\begin{array}{c}\text { After } 60 \text { of doses of } \\
\text { medicines }\end{array}$ & Before treatment & $\begin{array}{l}\text { After } 60 \text { doses of } \\
\text { medicines }\end{array}$ \\
\hline $\mathrm{T} 4_{\text {free }}(\mathrm{pmol} /)$ & $7.22 \pm 1.16$ & $14.34 \pm 0.92 * * *$ & $7.32 \pm 0.17$ & $5.87 \pm 0.67$ \\
\hline $\mathrm{TSH}(\mathrm{IU} / \mathrm{ml})$ & $4.44 \pm 0.77$ & $1.29 \pm 1.05^{* * *}$ & $4.51 \pm 0.96$ & $6.71 \pm 0.96$ \\
\hline $\operatorname{Se}(\mu / \mathrm{ml})$ & $56.66 \pm 6.85$ & $107.02 \pm 8.54 * * *$ & $57.04 \pm 7.16$ & $60.53 \pm 8.45$ \\
\hline $\mathrm{CD}^{+}$ & $42.72 \pm 2.98$ & $58.34 \pm 3.14 * * *$ & $43.21 \pm 2.45$ & $44.32 \pm 2.86$ \\
\hline CD4+ & $24.53 \pm 2.76$ & $34.78 \pm 328 * * *$ & $24.32 \pm 2.54$ & $24.44 \pm 2.65$ \\
\hline $\mathrm{CD}^{+}$ & $16.23 \pm 1.68$ & $17.66 \pm 1.87$ & $16.78 \pm 1.98$ & $17.54 \pm 1.67$ \\
\hline IRI & $1.53 \pm 0.18$ & $1.97 \pm 0.15$ & $1.44 \pm 0.11$ & $1.39 \pm 0.09$ \\
\hline $\mathrm{CD} 9^{+}$(B-lymphocytes) & $13.58 \pm 2,48$ & $18.98 \pm 1,87$ & $13.83 \pm 2,84$ & $13.39 \pm 2,51$ \\
\hline NK cells $\left(\mathrm{CD} 16^{+}\right)$ & $14.83 \pm 2,72$ & $19.89 \pm 1,76$ & $14.83 \pm 2,72$ & $16.45 \pm 2,65$ \\
\hline TNF- $\alpha(\mathrm{pmol} / \mathrm{ml})$ & $26.77 \pm 6.72$ & $61.35 \pm 7.01 * * *$ & $27.65 \pm 6.21$ & $28.54 \pm 7.13$ \\
\hline INT- $\gamma(\mathrm{pmol} / \mathrm{ml})$ & $2.11 \pm 0.07$ & $4.08 \pm 0.09 * * *$ & $2.76 \pm 0.06$ & $2.45 \pm 0.08$ \\
\hline IL-2 (pmol/ml) & $3.12 \pm 0.76$ & $8.43 \pm 1.09 * * *$ & $2.67 \pm 0.68$ & $2.65 \pm 0.56$ \\
\hline IL-6 (pmol/ml) & $14.89 \pm 1.32$ & $41.93 \pm 1,76^{* * *}$ & $15.98 \pm 1.45$ & $14.78 \pm 1.54$ \\
\hline IL-4 (pmol/ml) & $0.070 \pm 0.008$ & $0.011 \pm 0.007 * * *$ & $0.891 \pm 0.009$ & $0.0773 \pm 0.006$ \\
\hline
\end{tabular}

Note: * - a reliable difference in indicators between groups $(\mathrm{p} \leq 0,5) ; * *$ - a reliable difference in indicators before treatment and after 60 doses of medicines $(\mathrm{p} \leq 0,5)$. 
decreased, and the average level of thyroid-stimulating hormone significantly increased by the end of the intensive therapy phase. The results obtained indicate a negative effect of second-line anti-tuberculosis drugs (ethionamide, prothionamide and PAS and others) on thyroid function, which was observed in other studies [13]. This fact necessitates timely screening of thyroid function during the treatment of drug-resistant tuberculosis. Since shifts in thyroid homeostasis most reliably reflects changes in the level of thyroid-stimulating hormone, this criterion for assessing thyroid function should be used to screen thyroid function [11].

The results of the study reveals deviations in the parameters of initial cellular immunity in both groups with the increasing of T-cells. 2 months later in patients of the observation group, has been receiving selenite sodium there was a significant increase of leukocytes and pan-lymphocytes $\left(\mathrm{CD}^{+}\right)$in comparison with the control. The levels of the subpopulations of T-helpers $\left(\mathrm{CD} 4^{+}\right)$and IRI also were increased in patients of observation group. (Table 1). In TB patients with $\mathrm{MDR}+\mathrm{SH}+\mathrm{Se}$ of observation group, the level of TNF- $\alpha$ increased more than twice after receiving selenite sodium. The level of INT- $\gamma$ increased in 2.3 times more in observation group when compared with control group. The content of IL-2 in the systemic blood flow of patients of observation group (MDR $\mathrm{TB}+\mathrm{SH}+\mathrm{Se}$ ) increased of 2.5 times compared with the control.

Level of IL-4 in MDR TB patients have been receiving selenium of observation group decreased compared with the control group.

\section{Discussion.}

Thus, the results of the study demonstrate an improving change in all branches of immunity in patients with multi-drug resistant tuberculosis and subclinical hypothyroidism with after 2 months receiving of selenite sodium. Intensifying of the immunity were accompanied by stimulation of thyroid function under the influence of selenite sodium. So, selenite stimulates both humoral and cellular immunity by restoring thyroid function. These results, as well as data of the effect of administration of thyroid hormone in vivo and in vitro, indicate an important role of thyroid hormones in modulating the activity of natural killer cells. The results are corresponding with other studies. $[2,3,4,7]$, showing a positive association of thyroid hormone concentration with inflammatory markers activated by T-cells, NK-interleukin- 6 expression by activated monocytes, and a higher density of interleukin-2 receptors in $T$ cells and thus shedding light on the mechanisms by which the endocrine system is able to influence the severity of immunity. Besides, it' $s$ also impossible to exclude immune-stimulating effect of selenium by itself $[1,9]$.

\section{Conclusions.}

1. In patients with multi-drug resistant tuberculosis and subclinical hypothyroidism initially low serum level of selenium was marked.

2. Selenite sodium in taken with $200 \mu$ every day during 2 months normalized serum level of selenium and restored thyroid function.

3 . The parameters of both branches of the immunity improved by administration of selenite sodium during 2 months.

4. Selenite sodium could be recommended for concomitant therapy in patients with multi-drug resistant tuberculosis and subclinical hypothyroidism after estimation of serum level of selenium.

\section{References}

1. Avery J.C., Hoffman P.R. Selenium, selenoproteins and immunity. Nutriens, 2018; 10(9): 1203-14

2. Csaba G., Pallinger E. Thyrotropic hormone (TSH) regulation of triidthyronine (T3) concentration in immune cells. Inflamm. Res., 2009; 58: 151-4

3. Davis S.L. Environmental modulation of the immune system via the endocrine system. Domest. Anim. Endocrinol., 1998. 15: $283-9$

4. Dorshkind K., Horseman N.D. The roles of prolactin, growth factor-I, and thyroid hormones in lymphocyte development and function: insights from genetic models of hormone and hormone receptor deficiency. Endocrine. Rev., 2000; 21: 292-312

5. Duntas L.H. Selenium and the thyroid: a close knit connection. Journal of Clin Endoxinol \& Metabol, 2010; 95 (12): $5180-8$

6. Drutel A. Selenium and thyroid gland: more good news for clinicians. Clin Endocrinol (Oxf), 2013; 78 (2): 155-64

7. Foster M.P., Jensen E.R., Montecino-Rjdriguez E., Leathers H., Horseman N., Dorshkind K. Humoral and cell-madiated immunity in mice with genetic deficiencies of prolactin, growth hormone, insulin-like growth factor-I, and thyroid hormones. Clin. Immunol., 2000; 96: 140-9

8. Frick L.R., Rapanelli M., Bussman U.A, Kleche A.J. et al. Involvement of thyroid hormones in the alterations of T-cell immunity and tumor progression. Biol. Psychiatry, 2009: 65 (11): 935-42

9. Hodkinson C.F., Simpson E.E.A., Beattie J.H., O'Connor J.M., Campbell D.J., Strain J.J., Wallace J.M. Preliminary evidence of immune function modulation by thyroid hormones in healthy men and women aged 55-70 years. J. Endocrinol., 2009; 202; 55-63

10. Kleche A.J. et al. Involvement of thyroid hormones in the alterations of T-cell immunity and tumor progression. Biol. Psychiatry, 2009; 65 (11): 935-42

11. Kohler S., Senn O., Saler L. et al Timing of Thyroxine Adjustment in Hypothyroid Patient: When are TSH Levels Stable. Journal of Thyroid Disorders and Therapy, 2011; 3: 31-35

12. Mahuad C., Bozza V., Pezzotto SM, Bay ML, Besedovsky H., del Rey A, Botasso O. Impaired immune responses in tuberculosis patients are related to weight loss that coexists with immunoendocrine imbalance. Clin. Exp. Immunol., 2007; 14 (3-4): 193-9

13. Matvyeyeva S.L., Shevchenko O.S., Pogorelova O.O. The function of thyroid gland in patients with multi-drug resistant tuberculosis. Antimicrobial Resistance \& Infection Control, 2017; 82(6): 2279-85

14. Stuss M., Michalska-Kasiczak M., Sewerynek E. The role of selenium in thyroid gland pathphysiology. Endokrynol. Pol., 2017; 68 (4): 440-54 